\title{
Isolation and characterization of polymorphic microsatellite loci for Pistacia chinensis Bunge (Anacardiaceae)
}

\author{
Zhaohong Ding and Jianbo Lu
}

College of Life and Environmental Sciences, Hangzhou Normal University, Hangzhou, 310036, China

Corresponding author: Jianbo Lu, E-mail: jianbo.lu@hznu.edu.cn

\begin{abstract}
Pistacia chinensis Bunge (Anacardiaceae) is a native, dioecious, perennial arbor, and an important bioenergy plant. Twelve microsatellite markers were developed for $P$. chinensis to evaluate genetic diversity and population genetic structure when this species was subject to landscape fragmentation. Twelve polymorphic microsatellite loci were developed in $P$. chinensis using a microsatellite-enriched genomic library based on magnetic beads. These loci were characterized in 24 individuals from three populations located on Thousand Island Lake, Zhejiang Province, China. The number of alleles per locus varied from three to sixteen. The observed and expected heterozygosity ranged from 0.1250 to 0.8750 and 0.2333 to 0.8917 , respectively. These microsatellite loci will be applied in further studies on the population genetic diversity and genetic structure of $P$. chinensis. This study will improve understanding of the effects of landscape fragmentation, and help conserve and manage the species.
\end{abstract}

Keywords: : Anacardiaceae, microsatellites, Pistacia chinensis, landscape fragmentation, population genetics

\section{Introduction}

Habitat fragmentation, the reduction of continuous habitat into several smaller spatially isolated remnants, is caused mainly by human activity and includes agricultural development, urbanization, and deforestation etc. (Young et al., 1996). It is a significant threat to the maintenance of biodiversity in many terrestrial ecosystems. Recently, more attention has been paid to the potential genetic consequences of anthropogenic habitat fragmentation on plants (Yuan et al., 2012). Dioecious species, which use a relatively uncommon sexual system with separate female and male individuals, constitute only $6 \%$ of angiosperms (Renner et al., 1995). Some studies have found that dioecious plants are more sensitive to change in population size and structure than self-compatible species because of the restricted number of mating groups within the population. Thus, they are also more sensitive to habitat fragmentation (Stehlik et al., 2008, Yu et al., 2011).

Pistacia chinensis Bunge (Anacardiaceae) is a dioecious, perennial, and deciduous arbor belonging to the Pistacia genus, which consists of at least 11 species of dioecious trees and shrubs (Ozden-Tokatli et al., 2010). P. chinensis is a widely distributed native tree in China because it has strong adaptability to poor habitats and adverse circumstances. Additionally, it has medicinal functions and its wood is economically useful ( $\mathrm{Li}$ et al., 2007). Moreover, P. chinensis is considered a good raw material for bio-diesel production because of the high content and quality of its oil (Li et al., 2010). In the study of its genus plants, Albaladejo et al. developed eight microsatellite primers from Pistacia Lentiscus (Anacardiaceae) by magnetic beads (Albaladejo et al., 2008). Similarly, Chen et al. used magnetic beads to develop microsatellite loci of Pistacia weinmannifolia (Anacardiaceae) distributed in Yunnan and Guizhou provinces 
of China, and obtained fourteen microsatellite primers, nine out of fourteen loci developed for $P$. weinmannifolia amplified in P. chinensis (Chen et al., 2011).

Knowledge about presence or absence of null alleles is critical in order to assess a marker system's behavior in subsequent analyses. One main cause of microsatellite null alleles is poor primer annealing due to nucleotide sequence divergence (point mutations or indels) in one or both flanking primers. Microsatellite null alleles are not a natural characteristic of a specific gene, and are essentially different from isozyme null alleles. There have been few studies on germplasm resources at the molecular level, genetic diversity, and genetic structure. Therefore, we isolated and characterized 12 microsatellite markers for $P$. chinensis that were successfully applied to describe the genetic diversity and population structure of this species when subject to landscape fragmentation.

\section{Materials and Methods}

Genomic DNA was extracted from silica gel-dried $P$. chinensis leaves collected from Thousand Island Lake (TIL) (29.22'$29^{\circ} 50^{\prime} \mathrm{N}, 118^{\circ} 34^{\prime}-119^{\circ} 15^{\prime} \mathrm{E}$ ) (Zhejiang, China) using a Plant Genomic DNA Kit (Tiangen, Beijing, China). Samples were collected from different individuals that were randomly distributed to avoid sampling the same clone. A microsatellite-enriched genomic library based on magnetic beads was constructed following the protocol of Tong et al. (2012). Total genomic DNA (about $300 \mathrm{ng}$ ) was digested with the restriction enzyme Msel (New England Biolabs, Beverly, Massachusetts, USA) for $1 \mathrm{~h}$ at $37^{\circ} \mathrm{C}$, and the fragments were immediately linked with an Mseladapter pair (F:5'-TACTCAGGACTCAT-3', R:5'-GACGATGAGTCCTGAG-3'). After ligation, the products were diluted in a 1:10 ratio and amplified with an Msel-N primer (5'- GATGAGTCCTGAGTA$\left.A N-3^{\prime}\right)$. The PCR conditions were as follows: initial denaturation at $95^{\circ} \mathrm{C}$ for $3 \mathrm{~min}$, followed by 20 cycles of $94^{\circ} \mathrm{C}$ for $30 \mathrm{~s}, 53^{\circ} \mathrm{C}$ for $1 \mathrm{~min}$, and $72^{\circ} \mathrm{C}$ for $1 \mathrm{~min}$, with a final extension cycle at $72^{\circ} \mathrm{C}$ for $8 \mathrm{~min}$. Then a $5^{\prime}$-biotinylated probe, $(\mathrm{AG})_{15^{\prime}}$ and streptavidin-coated magnetic beads (Promega, Madison, Wisconsin, USA) were used to hybridize and capture the PCR product. Enriched products were amplified with the Msel-N primers and the PCR products were purified using a TIANgel Midi purification Kit (Tiangen, Beijing, China). Purified DNA fragments were ligated into the pMD19-T vector (TaKaRa, Dalian, China) and then transformed into DH5a competent cells (TaKaRa).

A total of 210 clones were tested by PCR using the primer combination M13-47, M13-48, and (AG) ${ }_{15}$. A total of 104 unique clones were identified and sequenced on a $A B I 3730$ DNA Sequence Analyzer (Applied Biosystems, Foster City, California, USA) and 77 clones contained simple sequence repeats, of which 42 sequences were selected to design primers using Primer Premier 5.0 (PREMIER Biosoft International, Palo Alto, California, USA). The others were discarded because they were not suitable for designing primers. The optimum conditions of PCR and polymorphisms of these primers were tested with 12 individuals sampled from $P$. chinensis populations in TIL. The PCR reaction was performed under the following conditions: $95^{\circ} \mathrm{C}$ for $5 \mathrm{~min}$; 30 cycles with each cycle lasting $30 \mathrm{~s}$ at $94^{\circ} \mathrm{C}, 30 \mathrm{~s}$ at $51^{\circ} \mathrm{C}-59^{\circ} \mathrm{C}$ depending on the primer, and $30 \mathrm{~s}$ at $72^{\circ} \mathrm{C}$, with a final extension of $72^{\circ} \mathrm{C}$ for $8 \mathrm{~min}$. The $15 \mu \mathrm{L}$ of PCR reagents included about $50 \mathrm{ng}$ of genomic DNA, $0.25 \mathrm{mM}$ of each dNTP, $0.1 \mu \mathrm{M}$ of each primer, $1 \times \mathrm{PCR}$ buffer (containing $\mathrm{Mg}^{2+} 1.5 \mathrm{mM}$ ), and $1 \mathrm{U}$ of Taq DNA polymerase (Sangon, Shanghai, China). The products were resolved on $8 \%(\mathrm{~W} / \mathrm{V})$ polyacrylamide denaturing gel. A total of 12 loci were screened out for either lack of products or monomorphism. We further tested the remaining 12 polymorphic loci, which were labeled with one of the following fluorescent dyes: HEX, ROX, TAMRA, or 6-FAM. There were 24 individuals from three $P$. chinensis populations. The PCR products were scanned on an $A B I 3730$ automated sequencer with an internal lane standard, and then analyzed using GeneMapper 4.0 (Applied Biosystems). Finally, we obtained 12 polymorphic loci for $P$. chinensis (Table 1). These microsatellite loci varied in allele size from $129 \mathrm{bp}$ to $302 \mathrm{bp}$ and all the sizes of the amplification products were matched based on sequences for all primers. The number of alleles per locus varied from three to sixteen with an average of 6.7 (Table 1).

To assess the efficiency of the selected loci, we used 24 individuals of $P$. chinensis from three different populations (eight individuals from each population) in TIL (Hangzhou, China) under the same PCR conditions mentioned above. The genetic diversity indexes, including the number of alleles, and the observed and expected heterozygosity, were analyzed using GENEPOP v4.0 (Rousset, 2008). The polymorphism information contents (PIC) were calculated using CERVUS v3.0.3 (Kalinowski et al., 2007). Deviations from the Hardy-Weinberg equilibrium (HWE) and from the linkage equilibrium were tested using GENEPOP v4.0 with sequential Bonferroni adjustment (Rice, 1989).

\section{Results and discussion}

The results showed that the mean number of alleles per locus was 4.0, 3.3, and 3.5 at the population level, respectively. The observed and expected heterozygosity per locus ranged from 0.1250 to 0.8750 and 0.2333 to 0.8917 , respectively (Table 2). The average PICs were 0.5449 (range: 0.3589-0.7993), 0.4931 (range: $0.3047-0.7654$ ) and 0.5442 (range: $0.1948-0.8157$ ) within the three populations, respectively. No significant linkage disequilibrium $(P>0.05)$ was observed for each pair of loci. However, loci PC193 and PC205 in the Mainland population and loci PC193 in the Medium Island population were significantly deviated from HWE $(\mathrm{P}<0.05)$.

The 12 polymorphic microsatellite loci for $P$. chinensis were newly developed using a genomic enrichment library and characterized. These microsatellites are important tools for genetic studies on subjects such as genetic diversity, spatial genetic structure, mating system, and gene flow etc. in P. chinensis. Although microsatellite null alleles have the characteristics of universality, complexity and invisibility, using Hardy-Weinberg equilibrium tests, parent-offspring genotype analysis, and new primer design can test and estimate their frequency. Null 
alleles have significant effects on the results of genetic analysis, potentially decreasing population genetic diversity and increasing genetic differentiation among populations.

Table 1

Characterization of 12 new polymorphic microsatellite loci in Pistacia chinensis. ${ }^{\text {a }}$

\begin{tabular}{|c|c|c|c|c|c|c|c|}
\hline Locus & Primer sequences $\left(5^{\prime}-3\right)$ & $\begin{array}{c}\text { Repeat } \\
\text { motif }\end{array}$ & Size (bp) & A & $T_{a}(\mathrm{C})$ & $\begin{array}{c}\begin{array}{c}\text { Fluorescent } \\
\text { dye }\end{array} \\
\text { b }\end{array}$ & $\begin{array}{r}\text { GenBank } \\
\text { accession no }\end{array}$ \\
\hline $\mathrm{PCl}$ & $\begin{array}{l}\text { F:TATTGGAGAAGGAAGGGACG } \\
\text { R:TCGTTTGAGATACCTGCTGC }\end{array}$ & $(\mathrm{GA})_{7}$ & $283-298$ & 7 & $55^{\circ} \mathrm{C}$ & 6-FAM & KT780354 \\
\hline PC19 & $\begin{array}{l}\text { F:AGGAAAAACAGCAAACAAT } \\
\text { R:GCTTTACTCACCTCCCAT }\end{array}$ & $(\mathrm{AG})_{20}$ & $149-177$ & 4 & $51^{\circ} \mathrm{C}$ & 6-FAM & KT780355 \\
\hline PC44 & $\begin{array}{l}\text { F:ATTGGAGAAGGAAGGGGAC } \\
\text { R:GAGAATGTCATCATCGTTTG }\end{array}$ & $(\mathrm{GA})_{11}$ & $161-187$ & 4 & $56^{\circ} \mathrm{C}$ & HEX & KT780356 \\
\hline PC64 & $\begin{array}{l}\text { F:AAATAGGGAGAGGACTGGAG } \\
\text { R:ACTCTCGTTACCTTGTGCTT }\end{array}$ & $(\mathrm{AG})_{16}$ & $255-282$ & 10 & $54^{\circ} \mathrm{C}$ & HEX & KT780357 \\
\hline PC70 & $\begin{array}{l}\text { F:GCAACCAAAAATAAAAATCA } \\
\text { R:CGAATCACTCCCACTCTAAG }\end{array}$ & $\left(\mathrm{TC}_{29}\right.$ & $270-283$ & 16 & $55^{\circ} \mathrm{C}$ & 6-FAM & KT780358 \\
\hline PC96 & $\begin{array}{l}\text { F:TGAGAGTGAGAGAAGGTTGG } \\
\text { R:AGTAAGGGAGATTTAGCGAA }\end{array}$ & $(\mathrm{CT})_{10}$ & $295-300$ & 9 & $55^{\circ} \mathrm{C}$ & ROX & KT780359 \\
\hline PC106 & $\begin{array}{l}\text { F:ATGAAGAGGCTGTAGTTGAA } \\
\text { R:ACCACAAGGACTAAAGAGAA }\end{array}$ & $(\mathrm{CT})_{13}$ & $178-181$ & 3 & $56^{\circ} \mathrm{C}$ & TAMRA & КT780360 \\
\hline PC172 & $\begin{array}{l}\text { F: CTTCCCATTCACTTGTCC } \\
\text { R:GGTTAGTTTGCTCGCTCT }\end{array}$ & $(\mathrm{GA})_{21}$ & $178-200$ & 9 & $54^{\circ} \mathrm{C}$ & HEX & KT780361 \\
\hline PC189 & $\begin{array}{l}\text { F:TGAGTCCTGAGTAAGCAAATG } \\
\text { R:TTAGAGGGCGTGAAGATGTA }\end{array}$ & $(\mathrm{TC})_{8}$ & $222-272$ & 3 & $54^{\circ} \mathrm{C}$ & TAMRA & КT780362 \\
\hline PC193 & $\begin{array}{l}\text { F:TAAGGATGTTTGTGTGGAGG } \\
\text { R:TAAGGTTTTACCAAATGCCA }\end{array}$ & $(\mathrm{GA})_{16}$ & $210-223$ & 6 & $59^{\circ} \mathrm{C}$ & ROX & КT780363 \\
\hline PC196 & $\begin{array}{l}\text { F:CACGGTATCCATCTCCCTTT } \\
\text { R:AGTAAGGTGGTTCGGATGCT }\end{array}$ & $(\mathrm{CT})_{8}$ & 129-159 & 5 & $59^{\circ} \mathrm{C}$ & TAMRA & KT780364 \\
\hline PC205 & $\begin{array}{l}\text { F:AAAGTATCTGTTATGTTGGG } \\
\text { R:TGAGTCCTGATAAAACACAC }\end{array}$ & $(\mathrm{AG})_{14}$ & $292-302$ & 4 & $51^{\circ} \mathrm{C}$ & ROX & KT780365 \\
\hline
\end{tabular}

Table 2

Genetic properties of the 12 newly developed microsatellites of P.chinensis. ${ }^{\text {a }}$

\begin{tabular}{|c|c|c|c|c|c|c|c|c|c|c|c|c|c|c|c|}
\hline \multirow[b]{2}{*}{ Locus } & \multicolumn{5}{|c|}{ Mainland population $(\mathrm{n}=8)$} & \multicolumn{5}{|c|}{ Medium Island population $(\mathrm{n}=8)$} & \multicolumn{5}{|c|}{ Micro Island population $(\mathrm{n}=8)$} \\
\hline & $\mathrm{Na}$ & Ho & $\mathrm{He}$ & $\mathrm{P}^{\mathrm{b}}$ & PIC & $\mathrm{Na}$ & Ho & $\mathrm{He}$ & $\mathrm{P}^{\mathrm{b}}$ & PIC & $\mathrm{Na}$ & Ho & $\mathrm{He}$ & $\mathrm{p}^{\mathrm{b}}$ & PIC \\
\hline $\mathrm{PCl}$ & 3 & 0.8750 & 0.6750 & 0.1616 & 0.5556 & 3 & 0.7500 & 0.6583 & 0.3862 & 0.5439 & 3 & 0.6250 & 0.6917 & 0.4378 & 0.5749 \\
\hline $\mathrm{PCl} 9$ & 3 & 0.5000 & 0.5917 & 0.7325 & 0.4555 & 3 & 0.7500 & 0.5417 & 0.5062 & 0.4277 & 3 & 0.6250 & 0.6583 & 0.1049 & 0.5439 \\
\hline PC44 & 2 & 0.6250 & 0.5250 & 0.5637 & 0.3711 & 2 & 0.3750 & 0.5250 & 0.3865 & 0.3711 & 2 & 0.8750 & 0.5250 & 0.0866 & 0.3711 \\
\hline PC64 & 3 & 0.6250 & 0.6583 & 0.8866 & 0.5439 & 3 & 0.7500 & 0.6917 & 0.3398 & 0.5749 & 3 & 0.6250 & 0.7000 & 0.2998 & 0.5815 \\
\hline PC70 & 8 & 0.7500 & 0.8750 & 0.1558 & 0.7993 & 7 & 0.7500 & 0.8417 & 0.1178 & 0.7654 & 8 & 0.8750 & 0.8917 & 0.3026 & 0.8157 \\
\hline PC96 & 5 & 0.7500 & 0.8083 & 0.1447 & 0.7219 & 5 & 0.7500 & 0.8167 & 0.4309 & 0.7266 & 6 & 0.8750 & 0.8667 & 0.5509 & 0.7852 \\
\hline $\mathrm{PC} 106$ & 3 & 0.6250 & 0.5667 & 0.8013 & 0.4683 & 2 & 0.5000 & 0.4000 & 0.4250 & 0.3047 & 2 & 0.2500 & 0.2333 & 0.7815 & 0.1948 \\
\hline $\mathrm{PCl} 72$ & 3 & 0.8750 & 0.5750 & 0.2526 & 0.4465 & 3 & 0.7500 & 0.5667 & 0.5062 & 0.4683 & 3 & 0.7500 & 0.6917 & 0.2773 & 0.5749 \\
\hline PC189 & 3 & 0.5000 & 0.6583 & 0.1049 & 0.5439 & 2 & 0.8750 & 0.5250 & 0.0866 & 0.3711 & 2 & 0.5000 & 0.4000 & 0.4250 & 0.3047 \\
\hline $\mathrm{PC} 193$ & 4 & 0.1250 & 0.6917 & $0.0022^{*}$ & 0.5925 & 3 & 0.2500 & 0.4333 & $0.0050^{*}$ & 0.3706 & 3 & 0.1250 & 0.5750 & 0.0755 & 0.4465 \\
\hline PCl96 & 2 & 0.7500 & 0.5000 & 0.1266 & 0.3589 & 2 & 0.7500 & 0.5333 & 0.2193 & 0.3750 & 2 & 0.5000 & 0.5333 & 0.8501 & 0.3750 \\
\hline PC205 & 5 & 0.7500 & 0.7750 & $0.0053^{*}$ & 0.6816 & 4 & 0.6250 & 0.7250 & 0.3970 & 0.6179 & 5 & 0.6250 & 0.8083 & 0.1084 & 0.7219 \\
\hline \multicolumn{16}{|c|}{ Note: $\mathrm{Na}=$ number of alleles; $\mathrm{Ho}=$ observed heterozygosity; $\mathrm{He}=$ expected heterozygosity; $\mathrm{n}=$ number of individuals in the population } \\
\hline \multirow{2}{*}{\multicolumn{16}{|c|}{ 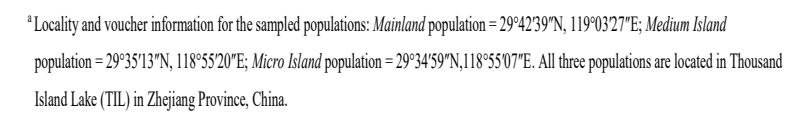 }} \\
\hline & & & & & & & & & & & & & & & \\
\hline & & & & & & & & & & & & & & & \\
\hline
\end{tabular}

\section{Acknowledgements}

The authors thank Xiaoyong Chen, Yuanyuan Ding, Zhenmin Chen and Yuqiang Sun for their assistance in conducting the experiments and comments on the manuscript. This study was supported by the National Natural Science Foundation of China (grant No. 31361123001) and the College Science and
Technology Innovation Activities Plan just as Planted Talents Program of Zhejiang Province (grant No. 2014R421076).

\section{References}

Albaladejo RG, Sebastiani F, Aparicio A, Buonamici A, González-Martínez SC, Vendramin GG (2008) Development and characterization of eight polymorphic microsatellite loci from Pistacia lentiscus L. (Anacardiaceae). Molecular Ecology Resources 8:904-906. https://doi.org/10.1111/j.1755-0998.2008.02110.x

Chen ST, Wu XY, Ji YH, Yang JB (2011) Isolation and characterization of microsatellite loci in Pistacia weinmannifolia (Anacardiaceae). International Journal of Molecular Sciences 12: 7818-7823. https://doi.org/10.3390/ijms12117818

Kalinowski ST, Taper ML, Marshall TC (2007) Revising how the computer program cervus accommodates genotyping error increases success in paternity assignment. Molecular Ecology 16: 1099-1106. https://doi.org/10.1111/j.1365-294X.2007.03089.x

Li HL, Zhang ZX, Lin SZ, Li XX (2007) Research advances in the study of Pistacia chinensis Bunge, a superior tree species for biomass energy. Forestry Studies in China 9: 164-168. https://doi.org/10.1007/s11632-007-0026-y

Li X, Hou S, Su M, Yang M, Shen S, Jiang G, Qi D, Chen S, Liu G (2010) Major energy plants and their potential for bioenergy development in China. Environmental Management 46: 579-589. https://doi.org/10.1007/s00267-010-9443-0

Ozden-Tokatli Y, Akdemir H, Tilkat E, Onay A (2010) Current status and conservation of Pistacia germplasm. Biotechnology Advances 28: 130-141. https://doi.org/10.1016/j.biotechadv.2009.10.006

Renner SS, Ricklefs RE (1995) Dioecy and its correlates in the flowering plants. American Journal of Botany 82: 596-606. https://doi.org/10.1002/j.1537-2197.1995.tb11504.x

Rousset F (2008) GENEPOP'007: A complete re-implementation of the genepop software for Windows and Linux. Molecular Ecology Resources 8: 103-106. https://doi.org/10.1111/j.1471-8286.2007.01931.x

Stehlik I, Friedman J, Barrett SCH (2008) Environmental influence on primary sex ratio in a dioecious plant. Proceedings of the National Academy of Sciences of the United States of America 105: 10847-10852. https://doi.org/10.1073/pnas.0801964105

Tong X, Xu NN, Li L, Chen XY (2012) Development and characterization of polymorphic microsatellite markers in Cyclobalanopsis glauca (Fagaceae). American Journal of Botany 99: e120-e122. https://doi.org/10.3732/ajb.1100448

Young A, Boyle T, Brown T (1996) The population genetic consequences of habitat fragmentation for plants. Trends in Ecology \& Evolution 11: 413-418. https://doi.org/10.1016/0169-5347(96)10045-8

Yu L, Lu JB (2011) Does landscape fragmentation influence sex ratio of dioecious plants? A case study of Pistacia chinensis in the Thousand-Island Lake region of China. PLoS ONE. 6, e22903. https://doi.org/10.1371/journal.pone.0022903

Yuan N, Comes HP, Mao YR, Qi XS, Qiu YX (2012) Genetic effects of recent habitat fragmentation in the Thousand-Island Lake region of southeast China on the distylous herb Hedyotis chrysotricha (Rubiaceae). American Journal of Botany 99: 1715-1725. https://doi.org/10.3732/ajb.1200054 